Available Online at http://journal.unismuh.ac.id/index.php/otoritas

Otoritas : Jurnal Ilmu Pemerintahan, 8 (2), October 2018, 110-123

\title{
Resolving the Illicit Trade of Small Arms and Light Weapon through ASEAN Ministerial Meeting on Transnational Crime (AMMTC)
}

\author{
Putti Ananda Hiswi*) \\ Department of International Relations, Faculty of Social and Political Sciences Universitas Indonesia, \\ Kampus Baru UI Depok, 16424 Jawa Barat, indonesia.
}

Received: 26 May 2018; Revised: 12 June 2018; Accepted: 21 June 2018

\begin{abstract}
This paper analyses the cooperation of states in Southeast Asia within the framework established by ASEAN, that is ASEAN Ministerial Meeting on Transnational Crime (AMMTC) to resolving the illicit trade of Small Arms and Light Weapon in the region. Most of existing works on the topic being studied put emphasize on the importance of the existence of norms, the role of institutions and security cooperation in resolving the illicit weapons trade. However, the existing studies have not explained why the existing form of cooperation has not been effective. By the approaching of international regime theory, this article explains the interest based of regime that explain the background of regime formation which could influence state behavior to cooperate and successfully implement the rules of the international regime itself. The research applying qualitative research methods with data sourced from primary and secondary data from ASEAN official documents, books, journals, online news. This article shows that the effectivity of AMMTC to deal with the illicit Small Arms Trade is strongly influenced by the implementation commitment of the state members.
\end{abstract}

Keywords: ASEAN; Small Arms and Light Weapon; International Regime; Illicit Weapons Trade

How to Cite: Hiswi, P. A. (2018). Resolving the Illicit Trade of Small Arms and Light Weapon through ASEAN Ministerial Meeting on Transnational Crime (AMMTC). Otoritas : Jurnal Ilmu Pemerintahan, 8(2), 110-123.

Permalink/DOI: https://doi.org/10.26618/ojip.v8i2.1311

${ }^{*}$ Corresponding Author.

E-Mail : putti.ananda@ui.ac.id

Copyright (C) 2018, Otoritas : Jurnal Ilmu Pemerintahan, ISSN: 2088-3706 (Print), ISSN: 2502-9320 (Online) 


\section{INTRODUCTION}

The threats to the state in the region evolve as the increasing interaction in international relation. The threats are not only in the form of traditional security such as military threats, but also nontraditional threats such as terrorism networks or transnational crime that could potentially trigger intrastate conflicts. One of transnational crime threat to the state in the region is illicit trafficking of the small and light weapons (Small Arms and Light Weapon, hereinafter abbreviated to SALW), which can be misused by any actor in the Southeast Asian region and implicate the stability of the region. For the period 2013 to 2017, as the global arms imports increase, the main recipient region was the Asia-Oceania by almost $42 \%$ of global imports and $22 \%$ of its imports received by Southeast Asia region (Wezeman \& Et.al, 2018). Southeast Asian states alone are the second largest importer of weapons to the Asian region from 2007 to 2014 (Holtom \& Pavesi, 2017). In addition, there is a connection between increased global arms trade and the risk of misuse and illicit trafficking of weapons.

The circulation of SALW or its illicit trade in Southeast Asia itself can not be separated from the long history of war that occurred in the region. The remnants weapons of the conflict were exploited by irresponsible parties and ended up in the hands of non state actor, such as separatist movement. Illicit SALW circulating in Southeast Asia were generally the remnants of the Vietnam and Cambodian war that inherit about 2 million firearms and 150,000 tons of ammunition utilized by the black market (Chouvy, 2013). The illicit SALW trafficking routes within Southeast Asia are through Myanmar, Indonesia, Thailand, the Philippines and Malaysia (Nsia-Pepra \& Pearson, 2009). The uncontrolled spread of SALW in Southeast Asia has several impacts, such as contributing to high levels of violent crime in Indonesia, Malaysia, the Philippines and Thailand; insurgency in Aceh, Mindanao and Myanmar; increasing communal conflict in Maluku; and impending development in Cambodia (Kramer, 2001).

In addition, the illicit trade of SALW in many Southeast Asian states is also influenced by the inability of the state to provide effective security for civilian and encourage them to have SALW as selfdefense, lack of rules regarding the existence of SALW, lack of institutions or mechanisms that effectively monitor and limit the acquisition and transfer of weapons, as well as leaks in government arsenals (Pattugalan, 2004). These factors make ASEAN realized of the danger of threats from transnational crime that arise with the existence of this illicit trade of SALW to the process of integration and security of the Southeast Asian region. Southeast Asia's states through ASEAN are committed in enhancing regional cooperation to combatting transnational crime. The efforts undertaken by ASEAN are to adopt the ASEAN Declaration on Transnational Crime and establish the ASEAN Ministerial Meeting on Transnational Crime (AMMTC) (Lee, 2014).

AMMTC becomes a discussion forum to solve transnational crime issues, especially related to illicit SALW circulation in the region. However, the meeting held every two years is still not fully able to solve the problem of illicit trade of SALW in the region. In addition, the AMMTC's ASEAN Plan of Action still focuses on other areas of transnational crime issues other than illicit SALW (ASEAN, 2017). On the other hand, the lack of rules and implementation to resolve the phenomenon of illicit trade of SALW could have implications for the potential risks of unfinished intrastate conflict, separatist and transnational crime network growth in each Southeast Asian states. During 2001 to 2014, the amount of SALW circulation 
that went into the region was not reduced showing that the implementation of the recommended rules by the region appears to be still not maximized (Holtom \& Pavesi, 2017). The existence of an effective transnational crime resolving mechanism is required to ensure security and stability within the region. The AMMTC that was established since the ASEAN Declaration on Transnational Crime in 1997 and providing an information exchange meeting discussing transnational crime once every two years should be able to become an ASEAN effort in addressing transnational crime issues occurring in the region, especially the illicit trade of SALW. The existing studies have not explained reasons behind the lack of implementation of the existing regional mechanisms on resolving the illicit trade of SALW in Southeast Asia.

Previous studies on the circulation and illicit trade of SALWs in Southeast Asia through ASEAN generally see it from three perspectives namely (1) norms, (2) institutions, and (3) security. The study examining in terms of norm formation discusses ASEAN as an institution that acts as a norm shaping try to promote SALW norms in the region. However, ASEAN became an actor who localized SALW as a transnational crime issue and dismisses the possibility of sensitive internal issues, such as military and police involvement in unlawful SALW transfers with the intention of limiting the scope of the effectiveness of the norm (Capie, 2008). ASEAN's awareness of taking responses to transnational crime had an impact on the securitization of member states on its domestic issues (Emmers, 2003; Haacke \& Williams, 2008; NsiaPepra \& Pearson, 2009). The securitization of issues by the member states should not make ASEAN restrain the issue of illicit SALW circulation into transnational or counter-terrorism criminal issues to influence the effectiveness of SALW circulation norms in the region.
The second perspective explains from the institutional point of view, which emphasizes that ASEAN as a regional organization in Southeast Asia recognizes the need to establish institutional instruments in response to resolving the illicit trade of SALW. However, some efforts by ASEAN through the ASEAN Political Security Community, AMMTC or ASEAN Regional Forum are constrained by the state's domestic priorities (Haacke, 2009; Kartha, 1999; Lee, 2014). The last perspective of studies were non-conventional security threats and response mechanisms. The problem of SALW's illicit trade in Southeast Asia is generally seen as a form of non-traditional crime involving actors of transnational crime network and closely connected to the inability of the state to exercise control as well as law enforcement in its sovereign territory (Bitzinger, 2013; Capie, 2008; Chouvy, 2013; Efrat, 2010; Evans, 1988; Fee, 1988; Pattugalan, 2004; Thachuk, 2007). The illicit trade of small arms, arms dealers, smugglers, and corrupt officials are some of the key contacts that could possibly encouraging the rise of trafficking connection and complex relation between transnational crime network with terrorist (Mullins \& Wither, 2016). The resolving effort for illicit trade of SALW must be done by not only involving the national government of one state but also coordinating cooperation with other states in the region. The uncontrolled of existing SALW all over the world has been a major factor in the increase in the number of conflicts and insecurity (Paoli \& Kytomaki, 2016). The circulation of SALW evolved from the remnants of the Vietnam-Cambodian war and with the background of the political-economic motives that caused the circulation and the illicit trade of SALWs increase in Southeast Asia. This resulted in a long chain that left ASEAN member states still lacking effective resolution mechanisms in the case of SALW. 
The three previous studies show the existence of norms and cooperation as an effort to resolve the circulation and illicit trade of SALW. However, the previous studies have not yet answered how the form and pattern of cooperation is implemented to ensure the state is committed in implementing norms and resolving the illicit trade of SALW in Southeast Asia. For this reason, this paper uses the theory of the international regime as an analytical framework to enrich the previous studies to understand the forms of cooperation and regime patterns in solving the problem of illicit trade of SALW as well as the factors that influence the regime effectivity. Therefore, this paper is intended to answer the research question "Why ASEAN Ministerial Meeting on Transnational Crime (AMMTC) has not been able to optimize its role on resolving the illicit trade of SALW in Southeast Asia?". To answer that question, this paper uses variables in the international regime that will help explain existing rules that should be implemented by member states to resolve the issues of illicit trade of SALW that can be achieved optimally. In the next section, this paper will explain the research methods, theoretical framefork of international regime, an analysis of the implementation of the regime in the resolving of illicit trade of SALW, and conclusions.

\section{RESEARCH METHODS}

This paper will use qualitative research methods with data sourced from primary and secondary data. The authors collected research data starting from the existence of the ASEAN Declaration on Transnational Crime which seeks to resolving the illicit trade of SALW in 1997 until the last meeting of AMMTC in 2017. The data was collected by conducting literature studies, news searches, especially from online media on the resolving of illicit SALW in Southeast Asia through ASEAN Ministerial Meeting on Transnational Crime (AMMTC). After the data is collected, triangulation will be done in order to test the accuracy of the research result. Triangulation is done by checking the validity and reliability of data through the comparison of data sources obtained from books, journals, online and articles in accordance with research questions.

\section{RESULTS AND DISCUSSION}

\section{International Regime}

The existence of international institutions encourages the formation of various form of agreements that serve as the basic rules of the relations between states. One form of agreement that is used as a basic rule is the international regime. The international regime is a principle, norm, rule and decision-making process (Krasner, 1982). The development of studies on international regimes in international relations itself has existed since 30 years ago through various works by Ernst B. Haas or Stephen D. Krasner (Hasenclever, Mayer, \& Rittberger, 1996).

Stephen D. Krasner defines regime as a set of principles, norms, rules and procedures for decision making, both explicit and implicit, in which actors expect to focus on a particular issue in international relations. The regime is more specific to an issue and generally involves limited members of the international community (Krasner, 1982). Ernst B. Haas also explains that the regime's focus is on arrangements to work together on topics and issues that are considered complex and cause interdependence so that interstate cooperation is necessary although not a comprehensive cooperation between all states (Haas, 1980).

Dirk Pulkowski also emphasize that the regime is a structure, not an actor. The regime is created by states, intergovernmental organizations, and nongovernmental organizations in the process of international socialization, which regulates common norms and principles to produce appropriate behavior on is- 
sues that reflect mutual interests (Pulkowski, 2014). Participation in the regime can encourage the same standard of behavior in dealing with an issue. International regime form by states while the existence of a regime can also alter and shape state behavior through commitment within the regime itself (Pulkowski, 2014). Pulkowski explained that intergovernmental organizations can act as international regime actors because international organizations can act as institutions that propagate norms and models of good political behavior (Pulkowski, 2014).

Krasner explains that if the principles, norms, rules, and procedures of decision-making of the regime become less coherent, or if the practice is inconsistent with principles, norms, rules and procedures, then the regime has weakened. Changes in the regime occur when there is a change in rules and procedures of decision-making, but not of norms or principles and the weakening of the regime occurs when incompatibility between regime components or inconsistencies between regimes and related behaviors (Krasner, 1982). Krasner also explains that there is a direct relationship between the background formation of the regime and the expecting behavior as in certain situations that are not fully conflicted, decision makers may lead to optimal results that make the regime significant (Krasner, 1982). Thus the factors behind the formation of the regime can greatly affect the end behavior of actors. The success of a regime implementation depends on the cooperation between states in implementing the regime. The cooperation is based on mutually agreed norms (Krasner, 1982).

The same perspective also stated by the explanation of Andreas Hasenclever, Peter Mayer and Volker Rittberger on the regime's effectiveness consisting of two ideas: first, the regime is effective as long as its members obey its norms and rules and secondly, an effective regime to the extent that it reaches a particular goal or fulfills its initial purpose (Hasenclever et al., 1996). As stated by Hasenclever, the existence of compliance mechanisms influence by the behavior of states in following the regime. Compliance mechanisms can happen if it can eliminate the fear of potentially deceive by their partners in the projected regime that has been agreed (Hasenclever et al., 1996).

Hasenclever extend the understanding of the regime by using a formal approach of the regime in which this approach was adopted into interest-based theories of regime derived from the development of Robert Keohane's regime studies (Hasenclever, Mayer, \& Rittberger, 2004). The regime's formal approach explained that the regime is considered as an explicit rule agreed upon by the actor and embodied in the agreement or other document (Hasenclever et al., 2004). This approach will further indicate the cause of the diversity of the regime's effectiveness. The interest-based theories of regime explain the state seeking its own interests under the assurance that the regime maximizes the interests of all actors involved (Keohane, 1984). In the interest-based theories of regime there are two characteristics that can explain the formation of the regime. First, contractualism, studying the effects of international regimes on the ability of actors to cooperate in dilemmatic situations. Second, situation-structuralisms, taking into strategic situation in which the actors may cooperate through the regimes with the intent of analyzing the implications of different constellation interests in the formation of regimes and institutional forms of the regime (Hasenclever et al., 2004).

Factors in the regime's formal approach will be applied in the analysis of illicit trade of SALW in Southeast Asia. Interest-based shows state trying to achieve its interests over the security of its territory from the threat of illicit trade of 
SALW. By analyzing those variables would be seen how the regime develops and should be applicable. The variables that will be used as the basic analysis in this paper are the variables of contractualism, situation-structuralism in the interest-based approach of the regime as described previously by Hasenclever et.al.

The success of the regime implementation was shown from the extent to which members behavior is in accordance with the rules and is strongly influenced by the reasons for the establishment of the regime itself. The regime is meant to facilitate the formation of agreements. Based on the analytical framework, this paper will explain the conformity of the illicit trade of SALW resolving policy implementation produced by the ASEAN Ministerial Meeting on Transnational Crime (AMMTC) based on the previously established regime-forming variables.

In the next part of this paper will be analyzed the formal approach of the regime applied in the interest-based theories of regime will see how the regime develops and effective. It will be seen how variables in the interest-based theories of regime fulfilled so as to have an effect on the implementation of the regime itself. Hasenclever et.al explains the effective regime as long as its members abide by its rules and a regime reaches the goal of its initial formation. Thus the initial reason for the formation of a strong regime can affect the success rate itself. Furthermore, it will be explained according to the formal approach regime, the resolving regime of illicit trade of SALW through AMMTC could not be optimize because of inapplicable factors of interest-based in that regime. A further explanation of the interest-based in the illicit trade of SALW resolving efforts through the AMMTC will be explained in the following chapters.

\section{Interest-Based in Resolving Illicit Trade of SALW Through AMMTC}

Interest-based emphasizes the role of the international regime that helps states realize their common interests in which the state is portrayed as a rational actors who cares only for the it gains (Hasenclever et al., 1996). In this case, the illicit trade of SALW resolving regime embodied by establishing the ASEAN Ministerial Meeting on Transnational Crime (AMMTC). The common interest to be achieved is to coordinate the behavior of the state in such a way that they can avoid the effects of the illicit trade of SALW.

Interest-based assumes a rational state confronted with the possibility of achieving mutual interest from their effective behavioral coordination will successfully solve the common problem of SALW's illicit trade threats. Thus the common interest encourages the state to make efforts to establish a set of specific norms and rules to deal with the illicit trade of SALW. The SALW'S illicit trade threats pushes ASEAN as a regional organization in Southeast Asia to take response and member states are expected to follow this response. However, the state is a rational actor who has a desire to achieve their own interests. The purpose of the regime will not be achieved if the collective interests that have previously been the driving force behind the establishment of the regime are not coheren with the initial interests of each state. The regime's effort in resolving SALW's illicit trade through AMMTC's regional mechanisms can be conflicted with the domestic interests of ASEAN member states themselves.

The Interest-based of resolving SALW's illicit trade through the AMMTC will further explain in two parts. The first subchapter explains contractualism in the establishment regime of the ASEAN Declaration on Transnational Crime 1997 which shows the state's interest in resolv- 
ing SALW's illicit trade. While the second sub-chapter is situation-structuralisms that will show the strategic situation and the implications of the constellation of the interests of each actors in the resolving efforts by the ASEAN Ministerial Meeting on Transnational Crime (AMMTC).

\section{Contractualism in the Formation of ASEAN Declaration on Transnational Crime 1997 as an International Regime}

Contractualism shows that the reason the state cooperate on a particular issue through the regime is because the state shares a common interest that they can achieve only through cooperation (Hasenclever et al., 1996). To achieve state interest, it is necessary to cooperate and share common interests in the areas of issues of concern to the regime. In this case the common interest is to resolving the illicit trade of SALW in Southeast Asia.

ASEAN is aware of the transnational crime issues, especially the illicit trade of SALW involving extensive networks between states in the region, requiring the regional cooperation not only one state effort. Contractualism shows that in general, ASEAN member states have a common interest that encourages them to cooperate to form a regime to solve SALW's problem through regional mechanisms. Despite that fact, some other state in Southeast Asia have different interests to the phenomenon of illicit trade of SALW itself. There are economic benefits from both legal and illicit trade of SALW (NsiaPepra \& Pearson, 2009). The arms trafficking transaction in Southeast Asia involves many intermediaries: traders and smugglers, criminals, government officials and intermediaries who coordinate the supply of weapons to various recipients (Nsia-Pepra \& Pearson, 2009). In order to control the dissemination and illicit trade of SALW, alternative economic activities are needed to replace the attractiveness arising from SALW's illicit trade and negotiations needed for regional policy.
ASEAN Declaration on Transnational Crime 1997 serves as a guideline for ASEAN member states to take measures to address the illicit trade of SALW in Southeast Asia. Through this declaration also emphasized the need for effective regional rules to combat this issue, especially on the aspect of information exchange and policy coordination (ASEAN, 2012). The Declaration becomes an institutional framework for ASEAN cooperation on transnational crime by establishing the ASEAN Ministerial Meeting on Transnational Crime (AMMTC) which meets every two years to coordinate the activities of the relevant ASEAN bodies such as the ASEAN Chiefs of National Police (ASEANAPOL) (ASEAN, 2012). Furthermore, from the principles and rules that existed from the ASEAN Declaration on Transnational Crime 1997 then generated the ASEAN Action Plan on transnational crime which contains the program plan that will be applied by ASEAN and member states in resolving problem of transnational crime (ASEAN, 2017). However, some efforts made by ASEAN through AMMTC are still constrained by domestic priorities of the states members.

The growth of illicit trade of SALW was responsible for most deaths in the world's conflict. Southeast Asia were known to be a region that has a long history of conflict from the Indochina war, including the Wars in Vietnam, Laos, Cambodia and Myanmar (Centre For International Law, 2017). Throughout the history of wars and conflicts within the region in Southeast Asia many have involved armed violence in every conflict (Chouvy, 2013). The history of the armed conflict has triggered the existence of a highly active and regionally integrated SALW illicit trade. In the 1990s, Cambodia emerged as a regional black market for SALW and its buyers include Myanmar rebel groups, separatists from Sri Lanka and supporters of the Aceh independence movement in Indonesia (Chouvy, 2013). In March 2010, 
thousands of grenades of ammunition and dozens of grenades vanished from the government arsenal in Phatthalung and the government claimed the weapons were used by red-shirt protesters in Bangkok (Chouvy, 2013).

SALW which is a portable weapon, easy to carry and hidden was most destructive weapon. The existence of SALW made it responsible for $50-90 \%$ of victims in the civil war until now (Nsia-Pepra \& Pearson, 2009). In addition to demand from buyers throughout the region, poverty and economic problems, political crises, armed conflicts and natural disasters can encourage actors to smuggle and trade illicit SALW (Nsia-Pepra \& Pearson, 2009). Southeast Asia states only have the ability to develop and produce SALW, considering the fact that the market of SALW itself becomes important to support the domestic supply and the state's economic sector of defence industry (Bitzinger, 2013). But the absence of SALW rules itself facilitates access to the illicit trade of SALW (Pattugalan, 2004).

The existence of illicit weapons trade can disrupt the state's stability. States see illicit trade activities as a major threat because smugglers and traffickers have impact on state legitimacy by questioning the state's ability to control its own territory (Chouvy, 2013). The weapons of the remnants of the conflict and the war are exploited by irresponsible parties and end up in the hands of the parties. In this context it is seen that the common interest of ASEAN member states is the need to resolve the threat of transnational crime, especially the illicit trade of SALW in Southeast Asia. With the complexity of SALW's existing circulation and trade problems in Southeast Asia since the end of Indochina's prolonged conflict, regional efforts are needed to resolve the issue. This is because there are still many potential conflicts that have not been fully resolved and the existence of illicit trade of SALW may increase the risk of potential threats to conflict within states and transnational crime activities that threaten the stability of the region.

The common interest emphasized by contractualism in the ASEAN Declaration on Transnational Crime 1997 is the need for resolving the illicit trade in SALW regionally. With consideration of the threat to the stability of the region with the existence of SALW's illicit trade. However, as Hasenclever et.al stated in an interestbased understanding that the state is a rationalist actor who only wants to maximize their interests. Therefore, the common interest which initially became the driving force behind the establishment of the SALW illicit trade resolving regime through the AMMTC could not be optimized.

The AMMTC already has an action plan as an effort to resolving the transnational crime issues, including illicit trade of SALW would possibly conflicted with domestic state interests. ASEAN member states face different threats that make them have different definitions of the priority of resolving security threats (Lee, 2014). The majority of ASEAN states are still focusing on the resolving of crimes such as drug trafficking and terrorism as for that the effort on resolving illicit trade of SALW becomes less than optimal (Lee, 2014). In addition, the poverty and the development gap were still a priority of the main interests of majority ASEAN member states, causing AMMTC regional efforts made less than the maximum. The common interest that can encourage the regime is difficult to achieve because states do not share the same aspect of contractualism in term of common interests. With these differences of interest, the AMMTC is only meeting to discuss security issues without being able to encourage cstates to follow the recommendation action plan. 
Available Online at http://journal.unismuh.ac.id/index.php/otoritas

Otoritas : Jurnal Ilmu Pemerintahan, 8 (2), October, 2018, 118

Situation-Structuralism in the Formation of ASEAN Declaration on Transnational Crime 1997 as an International Regime

The Situation-structuralism broaden the perspective adopted in contractualism by considering the strategic situation in which actors may cooperate through the regime, and analyze the implications of different constellation of interests for the possibility of regime formation as well as for institutional form of the regime (Hasenclever et al., 1996). The regime may become relevant depending on the strategic situation underlying the existence of the regime itself. In this case of the strategic situation, explain the condition in which the need to address the threat of illicit trade of SALW. According to the situation-structuralism, in every particular strategic situation requires different treatment to achieve the relevant regime (Hasenclever et al., 1996). The strategic situation has encouraged ASEAN member states to sign agreements in the ASEAN Declaration on Transnational Crime 1997 to coopereate towards enhancing cooperation in the resolving of transnational crime issues. The situation also prompted the states that referred to the declaration to form the AMMTC and were willing to hold meetings every two years discussing transnational crime issues.

The situation which is critically considered regional urgency at that time indirectly encourages member states to collectively agree on the resolving illicit trade of SALW which is included in the framework of resolving transnational crime. Hasenclever et. al explained in the situation-structuralism there is a critical situation which states should agree on a clear order that determines the appropriate behavior under the regime. In order to that situation, they must develop procedures that convince the actor that the possibility of being cheated by other party was unlikely (Hasenclever et al., 1996). In situation-structuralism there is possible solution to the regime's effectiveness with regime collaboration involving the role of international organizations to ensure the suitability of behavior with regime or coordination of the regime that will continue to cooperate despite the fact that only a few states continue to follow the rules of the regime so that the overall compliance element not entirely necessary. However, this does not fully work within the framework of ASEAN where ASEAN is a regional organization that uses intragovernmental systems (Tripathi, 2015). Thus no one can encourage the state and assert explicitly that the rules of the regime have been implemented accordingly because in the mechanism of ASEAN there is no ultimate authority above the state.

Both solutions offered by situationstructuralism can be a strategic situation that encourages the effectiveness of the regime although there are various constellations of interests not fully able to work in this ASEAN mechanism. AMMTC is only facilitating ASEAN member states to discuss the transnational crime issues facing their respective states and expect a recommendation of resolution mechanisms with the assistance of regional coordination (ASEAN, 2015). Coordination of the regime will be difficult to achieve because the resolving illicit trade of SALW requires joint settlement not just compliance from one state. Resolving illicit trade of SALW involves a cross boundary network and there is a risk of the inability of the state to enforce the law in its territory that causes the illicit trade to increase in Southeast Asia. The regional mechanism has purpose to help states enforce the law to overcome illicit trade of SALW. Thereby expecting incomplete compliance similarly to let the illicit trade of SALW continue to grow.

Another possibility of a situationstructuralism is the collaboration of the regime with international organizations in which ASEAN becomes a regional or- 
ganization facilitating the establishment regime to resolving the illicit trade of SALW through the AMMTC. But the function of international organizations that should be able to force states to abide by the rules of the regime itself is constrained by ASEAN's non-interference and intergovermental principles. The regime intended to facilitate the exchange of information about the existence of SALW in the region becomes difficult because AMMTC itself is only a communication forum and can not encourage the state to be fully transparent on the circulation of its transfer SALW. The AMMTC can only provide recommendations for joint policy coordination that member states can engage in armed trafficking but there is no enforcement mechanism that will ensure member states comply with the collective agreement.

The contractualism and situationstructuralism shows that the actors are well aware of their interests and the preference in the formation of cooperation is very influential on the negotiations between states (Hasenclever et al., 1996). Both components indicate that the importance of the state is very influential on the regime that will affect the success of cooperation that became the goal of the regime itself. The influence of different constellations of interests and situations underlying different regimes led to the resolving of SALW's illicit trade through AMMTC is indeed difficult. Member states are still focused on their respective domestic interests so that the elements of regulatory compliance are difficult to fulfill. In addition, the characteristic of ASEAN itself which is an intergovernmental regional organization can not force its member states to fully prioritize the problem of illicit trade of SALW compared to other transnational crime issues.

ASEAN recognizes the need for regional stability and security that will impact on the security of ASEAN member states. However, with only bianuall meet- ing AMMTC is less able to maximize its role in coordinating the illicit trade of SALW resolving policy. In several AMMTC meetings the focus of the agenda is on terrorism in the region (ASEAN, 2017). The problem of SALW's illicit trade is indeed one of the components of the AMMTC itself but in reality, the action plans and policy recommendations issued focus more on the issue of transnational crimes other than the SALW black trade.

AMMTC effort on resolving illicit trade of SALW include the exchange of information to establish compilations of ASEAN member states laws and regulations relating to arms smuggling, enhancing information exchange and cooperation among ASEAN officials such as ASEANAPOL, customs and regulators legislation on weapons smuggling activities. In addition, AMMTC also coordinates with ASEANAPOL on information about SALW's illicit trade activities, enhancing additional regional cooperation programs including enhancing information exchange with ASEAN dialogue partners, relevant regional organizations and relevant UN agencies (POA-ISS, 2005). The cooperation is intended to share important information about the identity, movements and activities of transnational criminal organizations known to be involved in illicit trade of SALW.

The resolving effort can not decrease the amount of illicit trade of SALW in Southeast Asia. Based on the data above, there is an increasing value of small arms supplied to Southeast Asia and the annual average value of the SALW flows to Southeast Asia during 2001 to 2014 reach to USD 214 million where Indonesia and Thailand are the main importers (Holtom \& Pavesi, 2017). Parts of Southeast Asian imports represented 5\% of global arms imports in 2001, but increased by $36 \%$ in 2014 (Holtom \& Pavesi, 2017). Throughout 2001 to 2014, SALW's entry into the region did not diminish (Holtom \& Pavesi, 2017). There is connec- 
tion between legal and illicit trade of SALW where an increase in the number of legal SALW circulations implies an increase in the number of illicit traffic of SALW (Nsia-Pepra \& Pearson, 2009). In addition, the legal SALW traffic circulars have similarities with illicit trade of SALW routes through Myanmar, Cambodia, Laos, Indonesia and Thailand (Nsia-Pepra \& Pearson, 2009). In the absence of SALW circulation rules and a lack of state capability to enforce the law relating to leakage of government arsenal and misbehavior of officials causing circulation of SALW has the potential to fall into illicit trade of SALW.

Based on these data it can be seen that the role of AMMTC in resolving illicit trade of SALW was still not optimal. During its existence since ASEAN Declaration on Transnational Crime 1997 until now the resolving efforts of illicit trade in SALW still has not shown significant contrasting results with the increasing potential of threats. AMMTC that should be able to meet the needs of ASEAN member states by conducting meeting every two years as an effort to exchange information solving the problem of transnational crime. However, ASEAN Ministerial Meeting on Transnational Crime (AMMTC) role can not be optimize as states do not fully cooperate in solving the illicit trade of SALW. It shows that the components in the formation of the regime that should be fulfilled to make the regime significant were not fulfilled in that cases no compliance of AMMTC policy implementation through its action plan.

\section{CONCLUSION}

From the description above, this paper shows that the resolving illicit trade of small arms and light weapon (SALW) in Southeast Asia through AMMTC can be analyzed by looking at the formal approach of the regime applied in the interest-based theories of regime that show the development of the regime and the factors behind the formation of the regime until it can take effect. Interestbased in the regime shows that the contractual component of common interests that should be able to drive the success of the regime does not appear in the relations among ASEAN member states themselves. Common interests that should ex-

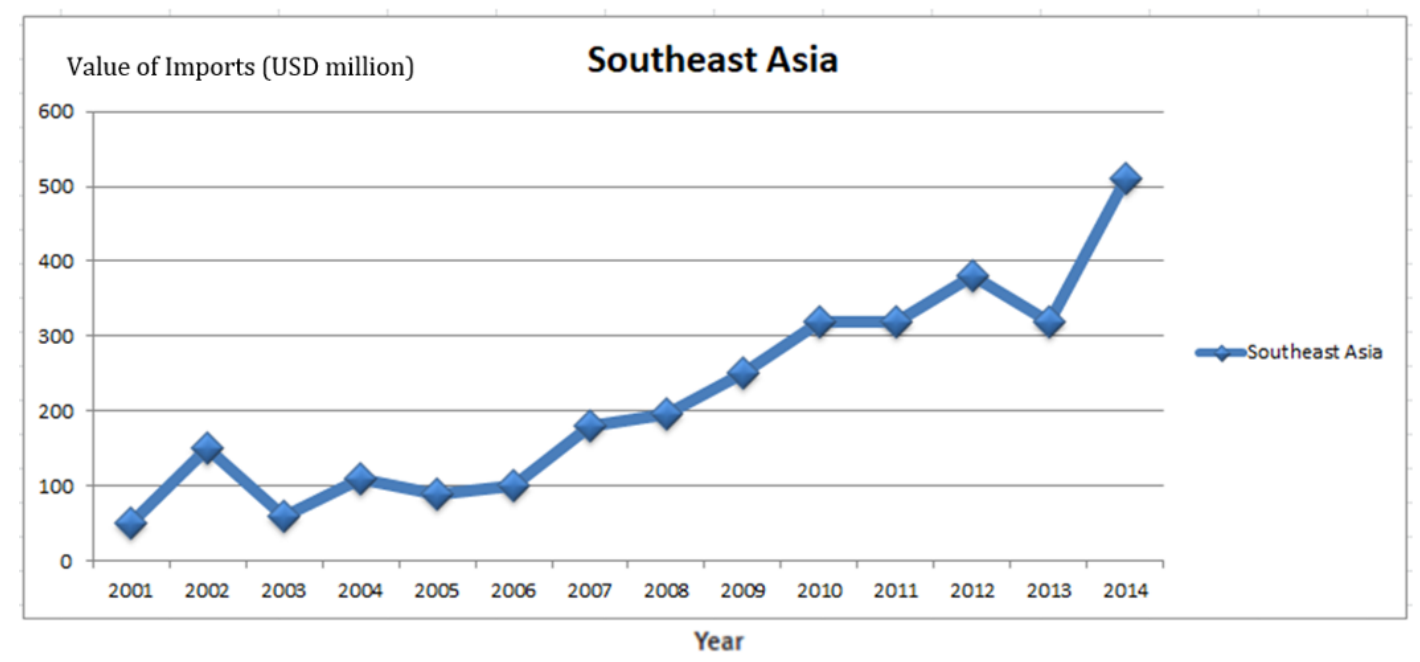

Note: All values are expressed in constant 2014 US dollars.

Source: NISAT (n.d.)

Figure 1. Value of Small Arms Supplied to Southeast Asia, as Reported to UN Comtrade (USD Million) 2001-2014

Source: Author's compilation based on data from NISAT by Holtom \& Pavesi, 2017 
ist clash with the interests of domestic priorities of each ASEAN member states. In addition to the situation-structuralism indicates that the underlying strategic situation is the need for resolving illicit trade of SALW that has the potential to threaten the security and stability of the region.

The constellation of interests that the regime should be able to accommodate, can not work on the framework of ASEAN which has the form of intergovernmental organization so that there is no mechanism that can ensure member states apply the regime in accordance with its provisions. The AMMTC is a state tools for resolving the transnational crime issues that include the resolving of SALW's illicit trade. AMMTC undertook SALW's illicit trade efforts by issuing action plans that support the establishment of inter-state cooperation in resolving SALW's illicit trade. However, the diverse interests of the state have an impact on the difficulty of conducting cooperation in accordance with the provisions recommended by AMMTC.

From the explanation, it is seen that the existing mechanism is not optimal because of the existence of different interests have an impact on the difficulty of the state to cooperate. Components in interest-based should be well met so as to produce an effective regime. However, the state is an rationalist actor who prioritizes their own interests so that the common interest element does not appear in the relationship between ASEAN members in terms of resolving illicit trade of SALW.

The findings in this study indicate that the effectiveness of the regime depends heavily on members who obey the norms and rules and the achievement of a particular goal or fulfillment of initial goals of the regime. In the context of the resolving of illicit trade in SALW, not all ASEAN member states regard this issue as a regional priority have an impact on some AMMTC agendas to resolving illicit trade of SALW were limited to only form of a cooperative recommendation unlike other transnational issues. Therefore, it would be best suggestion in order to optimize the resolving effort of illicit trade in SALW by AMMTC if ASEAN member states fully comply and commit to prioritize the resolving of this issues.

\section{ACKNOWLEDGEMENT}

I Sincerely thank to BU Dikti for providing me with the financial support during my study and research. I also would like to express my gratitude to my colleagues in the Department of International Relations Universitas Indonesia.

\section{REFERENCES}

ASEAN. (2012). ASEAN Declaration on Transnational Crime 1997. Retrieved April 28, 2018, from http://asean.org/?

static_post=asean-declaration-ontransnational-crime-manila-20december-1997

ASEAN. (2017). ASEAN Plan Of Action In Combating Transnational Crime (2016-2025). Retrieved April 9, 2018, from http://asean.org/ asean-political-securitycommunity/asean-ministerialmeeting-on-transnational-crimeammtc/

ASEAN, S. N. (2015). ASEAN Ministerial Meeting on Transnational Crime (AMMTC). Retrieved April 28, 2018, from http://setnasasean.id/asean-ministerialmeeting-on-transnational-crimeammtc

Bitzinger, R. A. (2013). Revisiting Armaments Production in Southeast Asia: New Dreams, Same Challenges. Contemporary Southeast Asia, 35(3), 369. https:// doi.org/10.1355/cs35-3c

Capie, D. (2008). Localization as re- 
Available Online at http://journal.unismuh.ac.id/index.php/otoritas

Otoritas : Jurnal Ilmu Pemerintahan, 8 (2), October, 2018, 122

sistance: The contested diffusion of small arms norms in Southeast Asia. Security Dialogue, 39(6), 637 $-658$. https:// doi.org/10.1177/096701060809 8213

Centre For International Law. (2017). ASEAN Plan Of Action In Combating Transnational Crime 20162025. Retrieved April 9, 2018, from https://cil.nus.edu.sg/wpcontent/uploads/ formidable/14/2016-2025ASEAN-POA-in-combatingtransnational-crime

Chouvy, P.-A. (2013). An Atlas of Trafficking in Southeast Asia: The Illicit Trade in Arms, Drugs, People, Counterfeit Goods and Natural Resources in Mainland Southeast Asia (Vol. 1).

Efrat, A. (2010). Toward internationally regulated goods: controlling the trade in small arms and light weapons. International Organization, 64(1), 97-131.

Emmers, R. (2003). ASEAN and the securitization of transnational crime in Southeast Asia. Pacific Review, 15(3), 419-438.

Evans, B. (1988). Arms Procurement Policies in ASEAN : is Enough? How Much is Enough? Contemporary Southeast Asia, 10(3), 294-305.

Fee, L. E. (1988). Arms Control in Southeast Asia : A Review of the Debate. Contemporary Southeast Asia, 10 (3), 221-241.

Haacke, J. (2009). The ASEAN Regional Forum: from dialogue to practical security cooperation? Cambridge Review of International Affairs, 22 (3), 427-449. https:// doi.org/10.1080/095575709031 04057
Haacke, J., \& Williams, P. D. (2008). Regional arrangements, securitization, and transnational security challenges: The African Union and the association of Southeast Asian Nations compared. Security Studies, 17(4), 775-809. https:// doi.org/10.1080/096364108025 08014

Haas, E. B. (1980). Why Collaborate? Issue -Linkage and International Regimes. World Politics, 32(03), 357 -405 .

Hasenclever, A., Mayer, P., \& Rittberger, V. (1996). Interests, Power, Knowledge: The Study of International Regimes, 40(2), 177-228.

Hasenclever, A., Mayer, P., \& Rittberger, V. (2004). Theories of international regimes. Cambridge: Cambridge University Press.

Holtom, P., \& Pavesi, I. (2017). Trade Update 2017 Out of the Shadows. Retrieved from http:// www.smallarmssurvey.org/ fileadmin/docs/S-Trade-Update/ SAS-Trade-Update-2017.pdf

Kartha, T. (1999). Trans-national crime and light weapons proliferation: Security implications for the state. Strategic Analysis, 23(9), 14491466. https:// doi.org/10.1080/097001699084 55136

Keohane, R. 0. (1984). After hegemony: cooperation and discord in the world political economy. Princenton: Princeton University Press.

Kramer, K. (2001). Legal controls on small arms and light weapons in Southeast Asia. Geneva: Small Arms Survey.

Krasner, S. D. (1982). Structural Causes and Regime Consequences: Regimes as Intervening Variables. 
Available Online at http://journal.unismuh.ac.id/index.php/otoritas

Otoritas : Jurnal Ilmu Pemerintahan, 8 (2), October, 2018, 123

International Organization, 36(2), 185-205. Retrieved from // www.jstor.org/stable/2706520

Kurniawan, Y. (2018). The politics of securitization in democratic Indonesia. Palgrave Macmillan. https:// doi.org/10.1007/978-3-31962482-2

Lee, Y. Y. (2014). Asean Matters! : Reflecting on the Association of Southeast Asian Nations. World Scientific Publishing.

Mullins, S., \& Wither, J. K. (2016). Terrorism and organized crime. UN Forum on Crime and Society, 15(3), 65-82.

Nsia-Pepra, K., \& Pearson, F. S. (2009). Official and illicit arms transfer data in Southeast Asia. Journal of Peacebuilding and Development, 5 (1), 101-108. https:// doi.org/10.1080/15423166.2009. 135301934648

Paoli, G. P., \& Kytomaki, E. (2016). Towards a Universal Arms Trade Treaty: Understanding barriers and challenges in South-East Asia. Retrieved from http:// www.rand.org/content/dam/ rand/pubs/research_reports/ RR1700/RR1779/ RAND_RR1779.pdf

Pattugalan, G. R. (2004). Small Arms Proliferation and Misuse : Impact Policy Actions Human Security Im pact and Policy Actions in South- east Asia. Journal of Third World Studies, 19(1), 62-91.

POA-ISS. (2005). The Issue of Small Arms and Light Weapons (SALW) in the context of trans-national organized crime: Its implications for ASEAN Security. Retrieved May 1, 2018, from http://www.poaiss.org/RegionalOrganizations/ ASEAN/The Issue of SALW in the context of transnations organized crime.pdf

Pulkowski, D. (2014). The Law and Politics of International Regime Conflict. Oxford: Oxford University Press. https://doi.org/10.1093/

acprof:oso/9780199689330.001.00 01

Thachuk, K. L. (2007). Transnational Threats: Smuggling and Trafficking in Arms, Drugs, and Human Life. International Relations. Praeger Security International.

Tripathi, M. (2015). European Union and ASEAN : A Comparison. International Journal of Research, 2(1), 376-383.

Wezeman, P. D., \& Et.al. (2018). Trend In International Arms Transfer 2017. SIPRI Fact Sheet, 7(March), 235249. 